\title{
CRP, an acute phase reactant: Role in Differentiating Bacterial and Non-Bacterial CNS Infections
}

\author{
Gedam DS \\ Dr D Sharad Gedam, MD, Editor-in-chief, IJMRR
}

Address for correspondence: Dr D Sharad Gedam, E-mail: editor.ijmrr@gmail.com

\begin{abstract}
$\mathrm{C}$ reactive protein is marker of acute inflammation. Now quantitative measurement of CRP is possible. Its quantitative measurement is better indicator of inflammation then qualitative one.
\end{abstract}

C reactive Protein is known acute phase reactant since $1930^{1}$. Its level increases with any kind of inflammation. Meningitis still remains very common reason for morbidity and mortality in developing countries like India. Although cerebrospinal fluid examination and Culture remains gold standard for diagnosis of meningitis but facilities are not easily available especially in emergency hours. There are very few studies available in literature to evaluate role of $\mathrm{C}$ reactive proteins in Cerebrospinal fluid to differentiate Non bacterial and bacterial CNS Infections ${ }^{2}, 3,4$. In developing countries patient usually reach to tertiary care centre after receiving various antibiotics. In this situation culture report is either negative or it takes few days before showing any result. Often CSF examination is not possible or show picture of partially treated meningitis. We give empirical antibiotics therapy in this situation.

Bejagavi et $\mathrm{al}^{6}$ in his study acute phase reactant Adenosine deaminase and CRP in Cerebrospinal fluid. ADA has a sensitivity and specificity of $73.9 \%$ and $92.6 \%$ respectively for Tubercular meningitis while CSF C- reactive Proteins have a sensitivity and specificity of $83.3 \%$ and $100 \%$ respectively for Pyogenic meningitis.

Other studies, 8, 9,10,11 have similar results. Sensitivity and specificity of CSF C reactive Protein was high for for Pyogenic meningitis. It also important tool to differentiate Viral and partially treated meningitis with Pyogenic meningitis. Measurment of other acute phase reactant with CSF C reactive Protein will further increases sensitivity and specificity of diagnostic tool.
Patel et $\mathrm{al}^{5}$. In his study he used CSF $\mathrm{C}$ reactive Protein as a bedside tool to differentiate between Bacterial and Non bacterial Meningitis. Results were very encouraging while awaiting result of CSF examination. Sensitivity and specificity was 83.3 and $87.5 \%$ respectively for Pyogenic meningitis. Similarly Positive predictive value was $75 \%$ and Negative predictive value was $92 \%$ for Bacterial meningitis. In tubercular meningitis sensitivity and specificity was $20 \%$ and $60.5 \%$ respectively. In viral meningitis CSF C reactive protein was negative in all cases. Similar results were seen with Mala et $\mathrm{al}^{2}$. In her study sensitivity and specificity was $96.87 \%$ and $74.73 \%$ respectively. For Tubercular meningitis sensitivity and specificity was $10 \%$ and $55.38 \%$.

This study ${ }^{5}$ has some limitations. They have used a Qualitative CRP kit which shows either positive or negative results. CSF $\mathrm{C}$ reactive proteins by measuring quantitative methods could have been better. This study included a small sample size. Thus while measuring CSF CRP as screening methods we need further study with larger sample size to show its efficacy. Similarly a larger control group should be taken for better analysis. Measurement of virological markers in CSF could have been done to diagnose viral meningitis.

Competing interest: None stated; Funding: Nil

\section{References}

1. Tillett WS, Francis T Jr. Serological reactions in pneumonia with a non-protein somatic fraction of Pneumococcus. J Exper Med 1980; 52:561-71

Available online at: $\underline{w w w . i j m r r . i n}$ $45 \mid \mathrm{P}$ a g e 


\section{Editorial}

2. Malla KK, Malla T, Rao KS, Basnet S, Shah R. Is Cerebrospinal fluid $C$ reactive Protein a better tool than blood $\mathrm{C}$ reactive Protein in Laboratory diagnosis of meningitis in children? Sultan Qaboos University Med J, 2013; 13(1): 9399

3. Corral CJ, Pepple JM, Moxon R, Hughes WT. C-reactive protein in cerebrospinal fluid in children with meningitis. $J$ Pediatr 1981;99:365-9.

4. Clarke D, Cost K. Use of serum C-reactive protein in differentiating septic from aseptic meningitis in children. $J$ Pediatr 1983;102:718-20.

5. Patel N, Patel U. Evaluating Utility of C-Reactive Protein in Differentiating Bacterial from Non-Bacterial Meningitis in Tertiary Care Hospital, In Central India Int J Med Res Rev 2013;1(2):47-55

6. Belagavi AC, Shalini M. Cerebrospinal fluid $\mathrm{C}$ reactive protein and adenosine deaminase in meningitis in adults. $J$ Assoc Physicians India. 2011;59:557-60.

7. Shimetani N, Shimetani K, Mori M. Levels of three inflammation markers, C-reactive protein, serum amyloid A protein and procalcitonin, in the serum and cerebrospinal fluid of patients with meningitis. Scand J Clin Lab Invest. 2001;61(7):567-74
8. Shimetani N, Ichikawa K, Shibuya M, et al. Quantitative levels of serum amyloid A protein and other proteins in cerebrospinal fluid and serum of patients with meningitis. Japanese Rinsho Byori. 1998;46(9):930-5.

9. Gendrel D, Raymond J, Assicot M et al. Procalcitonin, Creactive protein and interleukin 6 in bacterial and viral meningitis in children. French Presse Med 1998;27;27(23):1135-9.

10. Stearman M, Southgate HJ. The use of cytokine and Creactive protein measurements in cerebrospinal fluid during acute infective meningitis. Ann Clin Biochem 1994 ;31(3):255-61

11. Ahmad P, Ali SM, Fakhir S, Chandra J. C-reactive protein in CNS infection. Indian Pediatr 1991;28(10):116770.

\section{How to cite this article?}

Gedam DS. CRP, an acute phase reactant: Role in Differentiating Bacterial and Non-Bacterial CNS Infections.2013. Int J Med Res Rev 2013;1(2):45-46. doi: 10.17511/ijmrr.2013.i02.01 